\title{
Soil Microbial Attributes Under Agroforestry Systems in the Cerrado of Minas Gerais
}

\author{
Juliana Ribeiro Martins ${ }^{1}$, Luiz Arnaldo Fernandes ${ }^{1}$, \\ Agda Loureiro Gonçalves Oliveira ${ }^{1}$, Regynaldo Arruda Sampaio ${ }^{1}$, \\ Leidivan Almeida Frazão ${ }^{1}$
}

${ }^{1}$ Instituto de Ciências Agrárias, Universidade Federal de Minas Gerais - UFMG, Montes Claros/MG, Brasil

\begin{abstract}
The aim of this study was to evaluate the soil microbiological attributes of two Agroforestry Systems (AFS) in the city of Grão Mogol-MG considering two soil classes (Udox and Aqualf). Three composite samples were collected from the $0-5 \mathrm{~cm}$ soil depth layer. Each sample was subsequently divided into five replications to evaluate the carbon of soil microbial biomass (SMB-C), metabolic quotient $\left(\mathrm{qCO}_{2}\right)$, microbial quotient ( $\left.\mathrm{qMIC}\right)$, basal respiration (SBR) and the soil $\mathrm{CO}_{2}$ efflux. The microbiological attributes of the soil were more influenced by the season than by the AFS group. The BMS-C and SBR were higher in the dry season while the $\mathrm{CO}_{2}$ efflux was higher during the rainy season. The similar values of the microbiological attributes between the evaluated systems indicate that AFS are efficient at incorporating carbon and maintaining the soil biological activity similar to that of native vegetation areas.
\end{abstract}

Keywords: soil microbial biomass, $\mathrm{CO}_{2}$ efflux, conservation systems. 


\section{INTRODUCTION}

Agroforestry systems (AFS) provide constant soil cover and species diversification as well as being used to recover degraded areas. The diversification of plant species improves the chemical and physical properties of the soil, reducing the consumption of external inputs and increasing the efficiency of the production system (Araújo \& Melo, 2012).

The presence of tree species in the system contributes to the cycling of nutrients absorbed from the deeper soil layers by the roots and through decomposition of litter. In addition, many tree species can fix atmospheric nitrogen. In these systems, the litter supplies the nutrient requirements and plays an important role in the activity of organisms and soil carbon storage (Araújo \& Melo, 2012).

The quantification of carbon dioxide $\left(\mathrm{CO}_{2}\right)$ emissions by the microbes is used as an indicator of microbial activity and the decomposition stage of the waste and soil organic matter (SOM), given that $\mathrm{CO}_{2}$ is the result of the energetic metabolism of microorganisms (Wagner \& Wolf, 2009).

The quality of deposited material determines the litter composition which, on the other hand, influences the rate of nutrient cycling and soil microbial attributes (Nair et al., 2009). In a study comparing a native Cerrado with AFS in Piauí State, Iwata et al. (2012) found that microbial biomass and total organic $\mathrm{C}$ did not differ between systems at any evaluated depth.

Soil microbial biomass (SMB) is the main component of SOM and is the more active part of the soil, so it is used as an important indicator of changes in soil quality. Their use is due mainly to its relation to the ecological functions of the environment and the capacity to reflect the changes in soil land use (Jackson et al., 2003; Araújo \& Melo, 2010; Silva et al., 2012).

Several studies showed that AFS increased the activity of SMB by increasing plant diversity which thereby provides substrates with varied features that stimulate soil microbes and enhances environmental services (Duboc, 2008).

Pereira et al. (2008) showed that ASF have a low metabolic quotient and a high microbial quotient, indicating a good use of available carbon and a great ability of soil to stimulate microbial growth.
Microbial activity and root respiration are the main sources of $\mathrm{CO}_{2}$ production and are important components of the global C cycle (Fang \& Moncrieff, 1999). The soil $\mathrm{CO}_{2}$ exchange with the atmosphere needs to be better understood in order to determine the impacts of agricultural activities on soil carbon storage and microbial activity (Fernandes et al., 2002; Valentini et al., 2008).

Therefore, the aim of the present study was to evaluate the soil microbial attributes under agroforestry systems and to compare these with native Cerrado areas during dry and rainy seasons.

\section{MATERIAL AND METHODS}

This study was carried out at an Americana Agroextractivist Settlement located in the city of Grão Mogol, Minas Gerais State, Brazil $\left(16^{\circ} 17^{\prime} 55^{\prime \prime} \mathrm{S}\right.$ and $\left.43^{\circ} 17^{\prime} 41^{\prime \prime} \mathrm{W}\right)$. The settlement is located in the Cerrado biome and comprises 75 families in an area of 18 hectares.

We selected three different AFS with one hectare, according to floristic composition and soil classification. The study areas were implemented in 2003. The floristic composition and the numbers of individuals are shown in Table 1.

Two Agroforestry Systems (AFS1 and AFS2) were implanted in Oxisol soil in a dense Cerrado area, located on a hillside with a smooth-wavy relief. The AFS3 was implanted in Gleysol soil, on the same previously cited slope, in a gallery forest area located on an ancient floodplain with plan relief. For comparison purposes, we evaluated two native vegetation (NV) areas as a reference to determine the original condition of the soil (control): NV1 for AFS 1 and AFS 2; NV2 for AFS3.

We evaluated the systems in March and June 2013 including the end of the rainy season and the beginning of the dry season in the study region (Figure 1), respectively. In each evaluated area, we collected three composite samples at a $0-5 \mathrm{~cm}$ soil depth. Samples were sieved to $2 \mathrm{~mm}$ and visible organic matter was removed before analysis. In the laboratory, each soil sample was divided into five subsamples and stored in refrigerator at five degrees Celsius for 24 hours. Prior to starting the analysis, the soil samples were moistened to $60 \%$ water holding capacity. 
Table 1. Floristic composition of native vegetation (NV) and agroforestry systems (AFS) implanted at an Americana Agroextractivist Settlement located in the city of Grão Mogol, Minas Gerais State, Brazil.

\section{Family and species}

Number of individuals per hectare

$\begin{array}{lllll}\text { AFS1 } & \text { AFS } 2 & \text { NV } 1 & \text { AFS } 3 & \text { NV } 2\end{array}$

\section{Anacardiaceae}

Astroniun fraxinifolium Schott \& Spreng.

Lithraea molleoides (Vell.) Engl.

Mangifera indica L.

Tapirira guianensis Albl.

$\begin{array}{ccccc}100 & 100 & 20 & - & - \\ - & - & 80 & - & 420 \\ 80 & 20 & - & & \\ - & - & - & - & 20 \\ 20 & - & - & - & - \\ 20 & - & - & - & -\end{array}$

Annona crassiflora Mart.

Annona muricatan L.

Bignoniaceae

Handroanthus ochracea (Cham.) Mattos

Tabebuia aurea (Silva Manso) Benth. \& Hook. f. ex S. Moore

Tabebuia roseo alba (Ridl.) Sandwith

Bixaceae

Bixa orellana L.

Bombacaceae

Eriotheca pubescens (Mart. \& Zucc.) Schott \& Endl

Caricaceae

Carica papaya L.

Combretaceae

Buchenavia tomentosa Eichler

Terminalia argentea Mart.

\section{Euphorbiaceae}

Jatropha curcas L.

Fabaceae

Acosmium dasycarpum (Vogel) Yakole

Bowdichia virgilioides Kunth

Dalbergia miscolobium Benth.

Hymenaea courbaril (Hayne) Y.T. Lee \& Langenh.

Hymenaea stigonocarpa Mart. Ex Hayne

Leucaena leucocephala (Lam.) R. de Wit.

Machaerium opacum Vogel

Machaerium scleroxylon Tul.

Senna spectabilis (W. Schrad.) H. S. Irwin \& Barneby

Lamiaceae

Vitex montevidensis Cham.

Loganiaceae

Strychnus pseudoquina St. GH

Malpighiaceae

Malpighiae marginata Sessé \& Moc. ExDc.

Byrsonima intermediata A. Juss.

\section{Moraceae}

Brosimum gaudichaudii Trécul

\section{Musaceae}

Musa paradisiaca $\mathrm{L}$.

Myrtaceae

Eugenia dysenterica Mart. ex DC.

Source: Rocha et al. (2014), adapted. 20

40

$\begin{array}{ccccc}- & 60 & - & - & - \\ - & 20 & 40 & & \\ - & - & 80 & - & 40\end{array}$

$-$

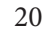

20

80

\section{0}

20

20 40

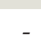


Table 1. Continued...

\begin{tabular}{|c|c|c|c|c|c|}
\hline \multirow{2}{*}{ Family and species } & \multicolumn{5}{|c|}{ Number of individuals per hectare } \\
\hline & AFS1 & AFS 2 & NV 1 & AFS 3 & NV 2 \\
\hline Psidium sp. & & & & - & 20 \\
\hline Psidium firmum $\mathrm{O}$ Berg. & & & & 180 & 260 \\
\hline Psidium gujjava L. & & & & 260 & - \\
\hline \multicolumn{6}{|l|}{ Nyctaginaceae } \\
\hline Neea theifera Oerst. & - & - & 80 & - & - \\
\hline Palmaceae & & & & - & - \\
\hline Syagrus flexuosa (Mart.) Becc. & 40 & - & 360 & - & - \\
\hline Rubiaceae & & & & - & - \\
\hline Tocoyena brasiliensis Mart. & - & - & 20 & - & - \\
\hline \multicolumn{6}{|l|}{ Rutaceae } \\
\hline Citrus limon (L.) Burm, f. & 20 & - & - & - & - \\
\hline Zanthoxylum riedelianum Engl. & 20 & - & 20 & - & 20 \\
\hline \multicolumn{6}{|l|}{ Sapindaceae } \\
\hline Magonia pubescens A. St. - Hil & 120 & 60 & 140 & - & - \\
\hline Tiliaceae & & & & - & - \\
\hline Luehea divaricada Mart. & 20 & 20 & - & - & - \\
\hline Vochysiaceae & & & & - & - \\
\hline Qualea grandiflora Mart. & - & 60 & 40 & - & - \\
\hline Qualea parviflora Mart. & 20 & - & - & - & - \\
\hline Total & 1000 & 560 & 1120 & 440 & 860 \\
\hline
\end{tabular}

Source: Rocha et al. (2014), adapted.

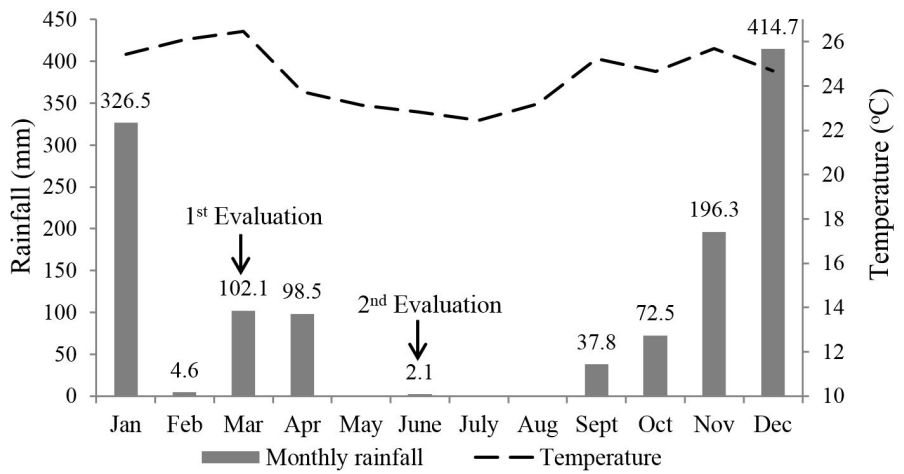

Figure 1. Rainfall and temperatures obtained by the Weather Station of Institute of Agrarian Sciences (ICA/UFMG) for 2013 in Montes Claros, Minas Gerais, Brazil.

The SMB-C was measured by the irradiation-extraction method and by the difference between irradiated and non-irradiated samples, according to Ferreira et al. (1999) and Silva et al. (2007a), adapted. Microbial activity was estimated by determination of soil basal respiration (SBR), obtained by incubating the soil samples for nine days and measuring the $\mathrm{CO}_{2}$ captured with $\mathrm{NaOH}$, according to the methodology proposed by Jenkinson \& Powlson (1976) and adapted by Silva et al. (2007b). The SBR calculation was obtained for the mean of the last three measurements of evolved $\mathrm{CO}_{2}$ during the evaluated period. After analysis, we determined the metabolic quotient (qCO2) obtained by the SBR and C-BMS ratio (Anderson \& Domsch, 1993) and microbial quotient (qMIC) by the BMS-C and Total Organic Carbon ratio (Sparling, 1997).

Soil respiration was measured using an automated soil $\mathrm{CO}_{2}$ flow system LCpro-SD model coupled to a bell ADC Soil Hood model. When the system is closed, air is circulated from a chamber to an infrared gas analyzer 
(IRGA) and then sent back to the chamber. Flow is estimated by the rate of $\mathrm{CO}_{2}$ concentration increase inside the chamber, which has been deployed on the soil surface for a short period of time. Measurements were taken between 8:00am, 11:00am and 1:00pm during rainy and dry seasons. Additionally, soil temperatures were recorded by a soil thermometer during each evaluated period, and volumetric soil moisture $(\theta \mathrm{V})$ was measured using LCpro-SD system (Table 2).

We calculated the average and the confidence interval for each evaluated parameter using the T Student Test $(\mathrm{p}<0.05)$.

\section{RESULTS AND DISCUSSION}

The SMB-C levels were different between the evaluated systems and the seasons studied. The high values observed in the two soil types were during the dry season (Table 3 ). We observed a low pluviometric index and temperatures in the study region (Figure 1).

Soil management with a greater increase of organic material due to anthropic action in the SAFs in detriment

Table 2. Soil water flow $\left(\mathrm{mmol} \mathrm{m}^{-2} \mathrm{~s}^{-1}\right)$ and temperature $\left({ }^{\circ} \mathrm{C}\right)$ in the agroforestry systems (ASF) and native vegetation $(\mathrm{NV})$.

\begin{tabular}{ccrrrrc} 
& & ASF 1 & ASF 2 & NV 1 & ASF 3 & NV 2 \\
\hline Rainy & $\mathrm{U}$ & 0.32 & 0.39 & 0.30 & 0.47 & 0.31 \\
season & $\mathrm{T}$ & 25.16 & 23.63 & 23.46 & 25.8 & 22.5 \\
\hline Dry & $\mathrm{U}$ & 0.08 & 0.13 & 0.08 & 0.11 & 0.16 \\
season & $\mathrm{T}$ & 19.33 & 19.37 & 18.70 & 20.17 & 18.27 \\
\hline
\end{tabular}

to the NV provided a greater availability of nutrients for the development of the microbial community, making BMS-C higher in the dry season. In addition, the maintenance of soil cover during the dry season conserved the soil moisture until the beginning of the rainy season. Similar results were found by Diniz et al. (2014) and Alves et al. (2011).

Silva et al. (2012), studying a secondary forest observed that SMB-C in the initial stage was higher in the dry season than the rainy season, while in the advanced stage the values showed no difference between the study periods. However, Alves et al. (2011), in a study comparing crop-livestock integrated systems with native vegetation and vegetation in regeneration, found higher values at SMB-C during the rainy season. The same results were found by Gama-Rodrigues et al. (2005) and Silveira et al. (2006).

The areas studied in Oxisol soil presented higher SMB-C values during rainy season (NV1) and dry season (ASF1). However, the areas studied in Gleysol soil showed no differences between the two evaluated seasons (Table 3).

In this study, the minor differences in SMB-C observed between the AFS's and native vegetation indicate that the management adopted in agroforestry systems also contributed to the microbial activity of the soil. According to Bandick \& Dick (1999), Menezes (2008) and Silva et al. (2012), greater plant biodiversity, soil management (without disturbance) and vegetation (with weeding) are some of the factors responsible for more favorable conditions to maintain SMB. Results similar

Table 3. Confidence interval of average $(n=15)$ of soil microbial biomass (SMB-C), soil basal respiration (SBR), soil $\mathrm{CO}_{2}$ efflux (IRGA), metabolic quotient $\left(\mathrm{qCO}_{2}\right)$ and microbial quotient (qMIC) at 0-5 cm soil depth in Agroforestry Systems (AFS) and Native Vegetation (NV) in the two seasons.

\begin{tabular}{|c|c|c|c|c|c|c|}
\hline \multirow{2}{*}{ Parameters } & \multirow{2}{*}{ Season } & \multicolumn{3}{|c|}{ 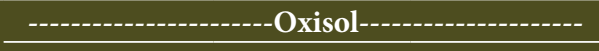 } & \multicolumn{2}{|c|}{-----------Gleysol------------ } \\
\hline & & AFS1 & AFS2 & NV1 & AFS 3 & NV2 \\
\hline \multirow{2}{*}{$\begin{array}{c}\text { SMB-C } \\
\left(\mathrm{mg} \mathrm{Cmic} \mathrm{kg}^{-1}\right)\end{array}$} & Rainy & $369.55 \pm 67.56^{*}$ & $285.29 \pm 67.49$ & $533.95 \pm 38.46$ & $175.80 \pm 8.26^{*}$ & $231.93 \pm 67.49$ \\
\hline & Dry & $862.96 \pm 118.34$ & $693.36 \pm 72.3$ & $606.44 \pm 64.17$ & $486.47 \pm 220.44$ & $518.04 \pm 95.45$ \\
\hline \multirow{2}{*}{ 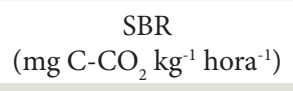 } & Rainy & $0.08 \pm 0.03^{*}$ & $0.12 \pm 0.02$ & $0.11 \pm 0.02$ & $0.12 \pm 0.02^{\star}$ & $0.16 \pm 0.04$ \\
\hline & Dry & $0.19 \pm 0.06$ & $0.19 \pm 0.03$ & $0.15 \pm 0.05$ & $0.18 \pm 0.05$ & $0.15 \pm 0.06$ \\
\hline \multirow{2}{*}{$\begin{array}{c}\mathrm{CO}_{2} \text { efflux } \\
\left(\mu \mathrm{mol} \mathrm{m}{ }^{-2} \mathrm{~s}^{-1}\right)\end{array}$} & Rainy & $3.50 \pm 1.40^{*}$ & $3.32 \pm 1.38$ & $2.69 \pm 0.42$ & $2.75 \pm 0.12^{\star}$ & $3.54 \pm 1.87$ \\
\hline & Dry & $1.18 \pm 0.21$ & $1.25 \pm 0.27$ & $0.85 \pm 0.13$ & $0.49 \pm 0.07$ & $0.84 \pm 0.06$ \\
\hline \multirow{2}{*}{$\begin{array}{c}\mathrm{qCO}_{2} \\
\left(\mathrm{mg} \mathrm{C}-\mathrm{CO}_{2} \cdot \mathrm{g}^{-1} \mathrm{Cmic} \mathrm{h}^{-1}\right)\end{array}$} & Rainy & $0.23 \pm 0.06^{* *}$ & $0.43 \pm 0.09$ & $0.20 \pm 0.05$ & $0.69 \pm 0.18^{\star *}$ & $0.69 \pm 0.31$ \\
\hline & Dry & $0.41 \pm 0.07$ & $0.23 \pm 0.08$ & $0.32 \pm 0.03$ & $0.38 \pm 0.12$ & $0.61 \pm 0.18$ \\
\hline \multirow{2}{*}{ qMIC (\%) } & Rainy & $1.19 \pm 0.28^{\star *}$ & $1.00 \pm 0.48$ & $1.12 \pm 0.32$ & $1.20 \pm 0.26^{* *}$ & $1.19 \pm 0.20$ \\
\hline & Dry & $1.34 \pm 0.42$ & $1.09 \pm 0.30$ & $1.36 \pm 0.52$ & $1.02 \pm 0.72$ & $1.03 \pm 0.86$ \\
\hline
\end{tabular}

${ }^{*}$ and ${ }^{* *}$ Significant averages \pm confidence interval by T Student Test $(\mathrm{p}<0.05)$. 
to those of this study were also observed by Silva et al. (2016) with higher BMS-C in agroforestry systems that showed greater species diversity. According to Dias et al. (2010), species richness contributes to a higher BMS-C because it interferes with the efflux of $\mathrm{CO}_{2}$ from the soil promoting its increase.

Similar results were also found by Pezarico et al. (2013) when comparing ASF and NV. According to the authors, the absence of soil disturbance in the soils results in a greater rhizosphere effect and accumulation of organic material on the soil surface, which is responsible for the biological diversity.

No differences were found between the $\mathrm{CO}_{2}$ emitted from the systems at each season evaluated. However, as was observed in SMB-C, the highest SBR values or mineralized carbon and $\mathrm{qCO}_{2}$ values were found in the dry season while almost no significant differences were found between the systems studied (Table 3). The SBR determined has been used to evaluate the metabolic activity of SMB, both aerobic and anaerobic microorganisms (Alef \& Nannipieri, 1995).

We found that the analyzed parameters were more sensitive to soil moisture and temperature than the land use changes (Figure 2). The similar values of SMB-C, SBR and $\mathrm{CO}_{2}$ efflux in AFS and NV indicate that the agroforestry systems incorporate plant residues, with a consequent accumulation of SOM at levels that also contribute to the high microbial biomass and biological activity.

In agricultural systems where soil use changed the SOM dynamics, the differences were clearly observed in microbial attributes. Silva et al. (2012) observed that SBR was higher in pasture and forest fragments than in cultivated areas with annual and perennial crops. According to these authors, the factors responsible for nutrient cycling and plant and microbial biomass renewal may have promoted lower respiration rates in soil under crop systems.

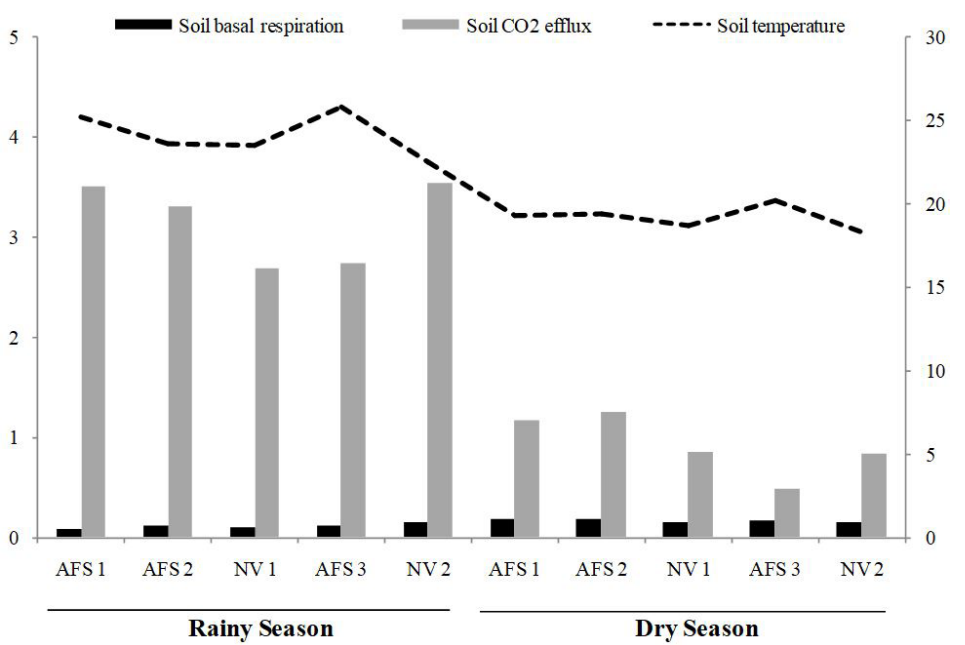

Figure 2. Means of soil basal respiration $\left(\mathrm{mg} \mathrm{C}-\mathrm{CO}_{2} \mathrm{~kg}^{-1}\right.$ hour-1), $\mathrm{CO}_{2}$ efflux $\left(\mu \mathrm{mol} \mathrm{m} \mathrm{m}^{-1}\right)$ and temperature $\left({ }^{\circ} \mathrm{C}\right)$ in the two evaluated seasons.

Table 4. Pearson correlation between soil $\mathrm{CO}_{2}$ eflux $\left(\mu \mathrm{mol} \mathrm{m} \mathrm{m}^{-2}\right)$, water flow $\left(\mathrm{mmol} \mathrm{m}^{-2} \mathrm{~s}^{-1}\right)$ and temperature during rainy and dry seasons.

\begin{tabular}{cccccc} 
& \multicolumn{5}{c}{ Rainy season } \\
\cline { 2 - 6 } & ASF1 & ASF2 & NV1 & ASF3 & NV2 \\
Water flow & $0.93^{* *}$ & $0.97^{* *}$ & $0.36^{\text {ns }}$ & $0.96^{* *}$ & $0.98^{* *}$ \\
Temperature $\left({ }^{\circ} \mathrm{C}\right)$ & $0.94^{* *}$ & $0.72^{*}$ & $0.60^{\text {ns }}$ & $0.96^{* *}$ & $0.84^{*}$ \\
\hline Water flow & & Dry season & & $-0.55^{\text {ns }}$ \\
\hline Temperature $\left({ }^{\circ} \mathrm{C}\right)$ & $0.22^{\text {ns }}$ & $0.99^{* *}$ & $-0.55^{\text {ns }}$ & $0.77^{*}$ & $-0.51^{\text {ns }}$ \\
\hline
\end{tabular}

${ }^{* *}$ and ${ }^{*}$ : significant at 0.01 and 0.05 , respectively. ns: not significant. 
According to Islabão et al. (2008), the constant incorporation of plant residues and accumulation of organic matter promotes an increase of microbial biomass and biological activity, resulting in increased $\mathrm{CO}_{2}$ emissions from forestry soils. On the other hand, Gama-Rodrigues et al. (2008) studying the soil microbial attributes under different vegetation coverings found that the areas of eucalyptus and grass had higher SBR than areas of the Atlantic Rainforest in secondary succession.

We found differences in $\mathrm{qCO}_{2}$ values between the systems and seasons evaluated. The higher values were found in the rainy season at AFS2, AFS3 and NV2 (Table 3). The microbial quotient (qMIC) was similar under the different conditions. These indexes indicate the efficiency of microbial biomass to use the available carbon for biosynthesis, being sensitive indicators to assess biological activity and soil quality (Saviozzi et al., 2002).

Silva et al. (2012) found higher $\mathrm{qCO}_{2}$ values during the rainy season than during the dry season, corroborating the results found in this study. Melloni et al. (2008) and Martins et al. (2010) affirm that high $\mathrm{qCO}_{2}$ values indicate higher carbon losses by microbial biomass. According to Diniz et al. (2014), high qCO2 values may indicate stress situations in the environment. On the other hand, low $\mathrm{qCO}_{2}$ and high SMB-C values indicate that the microbial biomass was more efficient at using organic compounds, releasing less $\mathrm{CO}_{2}$ and incorporating more carbon into the microbial tissues (Pulrolnik, 2009).

Thus, we suggest that agroforestry systems were efficient as native vegetation at using organic compounds. We can deduce that the microbial populations of both soil types and systems had similar energy requirements for their maintenance, since they did not differ significantly between the SMC-C and $\mathrm{qCO}_{2}$ values. Our results indicate that AFS's studied can reduce $\mathrm{CO}_{2}$ emissions over time when there is a more stable environment for the soil microbial community.

The qMIC values were higher than $1 \%$ in all evaluated systems. According to Jenkinson \& Ladd (1981) the qMIC values ranged from 1 to $4 \%$. Pezarico et al. (2013) found no differences between agroforestry systems and native forest. According to these authors, the stability of these systems favors the increase of organic matter in quantity and quality, benefiting the development of the soil microbial community.

The $\mathrm{CO}_{2}$ efflux from the soil showed no difference between the systems. Therefore, we observed higher values during the rainy season (Table 3). Corroborating the results obtained in this study, Fang \& Moncrieff (1999) studying Pinus elliottii plantations, observed that soil $\mathrm{CO}_{2}$ efflux was lower during autumn (low temperatures) and higher in summer (high temperatures). Similarly, Pinto-Junior et al. (2009) studying the Amazon Cerrado Transition Forest, found that soil $\mathrm{CO}_{2}$ efflux was higher during the transition between the dry and rainy period.

The $\mathrm{CO}_{2}$ efflux from the soil represents the $\mathrm{CO}_{2}$ released by the roots and microbial respiration and by the oxidation of organic matter, and it is important to determine the $\mathrm{CO}_{2}$ balance in the atmosphere (Davidson et al., 2002). Therefore, it is related to environmental factors as well as to soil use and management systems. The agroforestry systems are cited as an efficient management system to restore degraded land, control erosion and even influence climate effects such as improving water retention and precipitation (IPCC, 2014).

We observed a positive correlation between $\mathrm{CO}_{2}$ efflux with temperature and soil moisture, except in the native vegetation sites (NV1 and NV2) in rainy and dry season and AFS 1 and 2 during the dry season (Table 4). Both temperature and soil moisture can influence the soil respiration process, as well as the participation of microbial communities that depend on the temporal and spatial variability of these variables, as shown in Figure 2. The findings of this study corroborate those from studies by Bekku et al. (2003) and Valentini et al. (2008), which showed an exponential or linear increase in respiration rates as a function of increasing temperature.

\section{CONCLUSION}

Microbial soil attributes were more strongly influenced by the seasons than by the establishment of agroforestry systems. The results found here indicate that agroforestry systems incorporate $\mathrm{C}$ and maintain the soil biological activity similar to native systems. 


\section{SUBMISSION STATUS}

Received: 20 feb., 2017

Accepted: 26 jul., 2017

\section{CORRESPONDENCE TO}

\section{Leidivan Almeida Frazão}

Instituto de Ciências Agrárias, Universidade Federal de Minas Gerais - UFMG, Avenida Universitária, nº 1000, CEP 39404-547, Montes Claros, MG, Brasil

e-mail: lafrazao@ica.ufmg.br

\section{REFERENCES}

Alef K, Nannipieri P. Methods in applied soil microbiology and biochemistry. London: Academic Press; 1995.

Alves TS, Campos LL, Elias N No, Matsuoka M, Loureiro MF. Biomassa e atividade microbiana de solo sob vegetação nativa e diferentes sistemas de manejos. Acta Scientiarum. Agronomy 2011;33(2):341-347. http://dx.doi.org/10.4025/ actasciagron.v33i2.4841.

Anderson JPE, Domsch KH. The metabolic quotient $\left(\mathrm{qCO}_{2}\right)$ as a specific activity parameter to asses the effects of environmental conditions, such as $\mathrm{pH}$, on the microbial biomass of forest soils. Soil Biology \& Biochemistry 1993; 25(3): 393-395. http://dx.doi.org/10.1016/00380717(93)90140-7.

Araújo ASF, Melo WJ. Biomassa microbiana do solo. Teresinha: Universidade Federal do Piauí; 2012.

Araújo ASF, Melo WJ. Soil microbial biomass in organic farming system. Ciência Rural 2010; 40(11): 2419-2426. http://dx.doi.org/10.1590/S0103-84782010001100029.

Bandick AK, Dick RP. Field management effects on soil enzyme activities. Soil Biology \& Biochemistry 1999; 31(11): 1471-1479. http://dx.doi.org/10.1016/S00380717(99)00051-6.

Bekku YS, Nakatsubo T, Kume A, Adachi M, Koizumi H. Effect of warming on the temperature dependence of soil respiration rate in artic, temperature and tropical soils. Applied Soil Ecology 2003; 22(3): 205-210. http://dx.doi. org/10.1016/S0929-1393(02)00158-0.

Davidson EA, Savage K, Verchot LV, Navarro R. Minimizing artifacts and biases in chamber-based measurements of soil respiration. Agricultural and Forest Meteorology 2002; 113(1-4): 21-37. http://dx.doi.org/10.1016/S01681923(02)00100-4.

Dias ATC, Ruijven J, Berendse F. Plant species richness regulates soil respiration through changes in productivity. Oecologia 2010; 163(3): 805-813. http://dx.doi.org/10.1007/ s00442-010-1569-5. PMid:20169454.
Diniz T, Ramos MLG, Vivaldi LJ, Alencar CM, Junqueira NTV. Alterações microbianas e químicas de um gleissolo sob macaubeiras nativas em função da variação sazonal e espacial. Bioscience Journal 2014; 30: 750-762.

Duboc E. Sistemas agroflorestais e o cerrado. In: Faleiro FG, editor. Savanas: desafios e estratégias para o equilíbrio entre sociedade, agronegócio e recursos naturais. Planaltina: Embrapa Cerrados; 2008. p. 964-985.

Fang C, Moncrieff JB. A model for soil $\mathrm{CO}_{2}$ production and transport 1. Model development. Agricultural and Forest Meteorology 1999; 95(4): 225-236. http://dx.doi. org/10.1016/S0168-1923(99)00036-2.

Fernandes SAP, Bernoux M, Cerri CC, Feigl BJ, Piccolo MC. Seasonal variation of soil chemical properties and $\mathrm{CO}_{2}$ and $\mathrm{CH}_{4}$ fluxes in unfertilized and P-fertilized pastures in an Ultisol of Brazilian Amazon. Geoderma 2002; 107(3-4): 227-241. http://dx.doi.org/10.1016/ S0016-7061(01)00150-1.

Ferreira AS, Camargo FAO, Vidor C. Utilização de microondas na avaliação da biomassa microbiana do solo. Revista Brasileira de Ciência do Solo 1999; 23(4): 991-996. http://dx.doi.org/10.1590/S0100-06831999000400026.

Gama-Rodrigues EF, Barros NF, Gama-Rodrigues AC, Santos GA. Nitrogênio, carbono e atividade da biomassa microbiana do solo em plantações de eucalipto. Revista Brasileira de Ciência do Solo 2005; 29(6): 893-901. http:// dx.doi.org/10.1590/S0100-06832005000600007.

Gama-Rodrigues EF, Barros NF, Viana AP, Santos GA. Alterações na biomassa e na atividade microbiana da serapilheira e do solo, em decorrência da substituição de cobertura florestal nativa por plantações de eucalipto, em diferentes sítios da região sudeste do Brasil. Revista Brasileira de Ciência do Solo 2008; 32(4): 1489-1499. http://dx.doi.org/10.1590/S0100-06832008000400013.

Intergovernmental Panel on Climate Change - IPCC. Climate change 2014: mitigation of climate change. Cambridge: Cambridge University Press; 2014.

Islabão GO, Timm LC, Castilhos DD, Prestes RB, Bamberg AL. Carbono da biomassa e atividade microbiana em solos cultivados com morango no município de Turuçu/RS. In: Anais do XVII CIC e X ENPOS - Congresso de Iniciação Científica e Encontro de Pós-Graduação [online]; 11-14 nov 2008; Pelotas - RS. Pelotas: UFPel; 2008 [cited 02 may 2011]. Avaiable from: http://www2.ufpel.edu.br/ cic/2008/cd/pages/pdf/CA/CA_00507.pdf

Iwata BF, Leite LFC, Araújo ASF, Nunes LAPL, Gehring C, Campos LP. Sistemas agroflorestais e seus efeitos sobre os atributos químicos em Argissolo Vermelho-Amarelo do Cerrado piauiense. Revista Brasileira de Engenharia Agrícola e Ambiental 2012; 16(7): 730-738. http://dx.doi. org/10.1590/S1415-43662012000700005.

Jackson LE, Calderon FJ, Steenwerth KL, Scow KM, Rolston DE. Responses of soil microbial processes and community structure to tillage events and implications 
for soil quality. Geoderma 2003; 114(3-4): 305-317. http:// dx.doi.org/10.1016/S0016-7061(03)00046-6.

Jenkinson DS, Ladd JN. Microbial biomass in soil: measurement and turnover. In: Paul EA (Eds). Soil Biochemistry. Vol. 5. Rome: FAO; 1981. p. 415-471.

Jenkinson DS, Powlson DS. The effects of biocidal treatments on metabolism in soil - V. A. method for measuring soil biomass. Soil Biology \& Biochemistry 1976; 8(3): 209-213. http://dx.doi.org/10.1016/0038-0717(76)90005-5.

Martins CM, Galindo ICL, Souza ER, Poroca HA. Atributos químicos e microbianos do solo de áreas em processo de desertificação no semiárido de Pernambuco. Revista Brasileira de Ciência do Solo 2010; 34(6): 1883-1890. http://dx.doi.org/10.1590/S0100-06832010000600012.

Melloni R, Melloni EGP, Alvarenga MIN, Vieira FBM. Avaliação da qualidade de solos sob diferentes coberturas florestais e de pastagem no sul de Minas Gerais. Revista Brasileira de Ciência do Solo 2008; 32(6): 2461-2470. http://dx.doi.org/10.1590/S0100-06832008000600023.

Menezes CEG. Integridade de paisagem, manejo e atributos do solo no médio Vale do Paraíba do Sul Pinheiral-RJ. [tese]. Rio de Janeiro: Universidade Federal Rural do Rio de Janeiro; 2008.

Nair PKR, Kumar BM, Nair VD. Agroforestry as a strategy for carbon sequestration. Journal of Plant Nutrition and Soil Science 2009; 172(1): 10-23. http://dx.doi.org/10.1002/ jpln.200800030.

Pereira FH, Mercante FM, Padovan MP. Biomassa microbiana do solo sob sistemas de manejo com diferentes coberturas vegetais. Revista Brasileira de Agroecologia [online] 2008 [cited 2014 feb 15]; 3: 130-133. Available from: http://www.aba-groecologia.org.br/revistas/index. $\mathrm{php/cad/article/view/3255}$

Pezarico CR, Vitorino ACT, Mercante FM, Daniel O. Indicadores de qualidade do solo em sistemas agroflorestais. Amazonian Journal of Agricultural and Environmental Sciences 2013; 56: 40-47.

Pinto-Junior OB, Sanches L, Dalmolin AC, Nogueira JS. Efluxo de $\mathrm{CO}_{2}$ do solo em floresta de transição Amazônia Cerrado e em área de pastagem. Acta Amazonica 2009; 39(4): 813-821. http://dx.doi.org/10.1590/S004459672009000400009 .

Pulrolnik K. Transformações do carbono no solo. Planaltina: Embrapa Cerrados; 2009.

Rocha GP, Fernandes LA, Cabacinha CD, Lopes IDP, Ribeiro JM, Frazão LA et al. Caracterização e estoques de carbono de sistemas agroflorestais no Cerrado de Minas
Gerais. Ciência Rural 2014; 44(7): 1197-1203. http://dx.doi. org/10.1590/0103-8478cr20130804.

Saviozzi A, Bufalino P, Levi-Minzi R, Riffald R. Biochemical activities in a degraded soil restored by two amendments: a laboratory study. Biology and Fertility of Soils 2002; 35(2): 96-101. http://dx.doi.org/10.1007/s00374-002-0445-9.

Silva CF, Pereira MG, Miguel DL, Feitora JCF, Loss A, Menezes CEG et al. Carbono orgânico total, biomassa microbiana e atividade enzimática do solo de áreas agrícolas, florestais e pastagem no médio vale do Paranaíba do sul (RJ). Revista Brasileira de Ciência do Solo 2012; 36(6): 1680-1689. http://dx.doi.org/10.1590/ S0100-06832012000600002.

Silva CM, Vasconcelos SS, Mourão M Jr, Bispo CJC, Kato $\mathrm{OR}$, Silva AC Jr et al. Variação temporal do efluxo de $\mathrm{CO}_{2}$ do solo em sistemas agroflorestais com palma de óleo na Amazônia Oriental. Acta Amazonica 2016; 46(1): 1-12. http://dx.doi.org/10.1590/1809-4392201500193.

Silva EE, Azevedo PHS, De-Polli H. Determinação do carbono da biomassa microbiana do solo (BMS-C) [online]. Brasília: Embrapa; 2007a [cited 2014 feb 15]. (Comunicado Técnico; 98). Available from: http://www.cnpab.embrapa. br/comunicado-tecnico/COT098

Silva EE, Azevedo PHS, De-Polli H. Determinação da respiração basal (RBS) e quociente metabólico do solo (qCO2) [online]. Brasília: Embrapa; 2007b [cited 2014 feb 15]. (Comunicado Técnico; 99). Available from: http:// www.cnpab.embrapa.br/comunicado-tecnico/COT099

Silveira RB, Melloni R, Melloni EGP. Atributos microbiológicos e bioquímicos como indicadores da recuperação de áreas degradadas, em Itajubá/MG. Cerne [online]. 2006 [cited 2014 feb 20]; 12: 48-55. Available from: http://www.dcf.ufla. br/cerne/artigos/10-02-20093031v12_n1_artigo\%2006.pdf

Sparling GP. Soil microbial biomass, activity and nutrient cycling as indicators of soil health. In: Pankhurst C, Doube BM, Gupta VVSR. (Eds.). Biological indicators of soil health. Cambridge: CAB International; 1997.

Valentini CMA, Espinosa MM, Paulo SR. Estimativa do efluxo de $\mathrm{CO} 2$ do solo por meio de regressão múltipla para floresta de transição no noroeste do Mato Grosso. Cerne [online] 2008 [cited 2014 feb 12]; 14: 9-16. Available from: http://www.dcf.ufla.br/cerne/publicacao. php? volume $=14 \&$ numero $=1$.

Wagner GH, Wolf DC. Carbon transformations and soil organic matter formation. In: Pulrolnik K. Transformações do Carbono do Solo. Planaltina, DF; 2009. 